\title{
The health of the forest stand along urban routes of different traffic intensity in Szczecin
}

\section{Zdrowotność drzewostanu wzdłuż ciągów komunikacyjnych o różnym stopniu natężenia ruchu ulicznego w Szczecinie}

\author{
Magdalena Dzięgielewska ${ }^{1 *}$, Iwona Adamska ${ }^{2}$
}

\section{Summary}

The occurrence of specific insect pests and diseases on the three species of trees: Acer platanoides, Acer pseudoplatanus and Tilia platyphyllos in varying degrees air pollution of urban traffic routes was evaluated. In the two-year study (2014-2015) 11 species of fungi and 11 species of pests were recorded. The aphids Aphididae and eriophyoid mites Eriophyoidea were the most numerous among the pests identified on the trees, especially near traffic routes with high degree of air pollution. The same situation was observed for fungi. Two species of fungi: Discula umbrinella and Melasmia acerina were the most dominant and the latter one - has been considered an indicator species of urban air pollution.

Key words: pathogens; pests; population; urban greenery; anthropogenic impact

\section{Streszczenie}

Badano występowanie specyficznych szkodników i chorób na trzech wybranych gatunkach drzew rosnących wzdłuż ciągów komunikacyjnych o różnym stopniu zanieczyszczenia powietrza. Podczas dwuletnich badań (2014-2015) odnotowano 11 gatunków grzybów i 11 gatunków szkodników. Najliczniejsze wśród szkodników były mszyce i szpeciele, szczególnie w pobliżu dróg o wysokim stopniu skażenia zanieczyszczeniami. Podobne wyniki uzyskano w przypadku grzybów. Wśród dominujących grzybów wyróżniono dwa gatunki: Discula umbrinella i Melasmia acerina, który uważany jest za gatunek wskaźnikowy zanieczyszczenia powietrza.

Słowa kluczowe: patogeny; szkodniki; populacja; zieleń miejska; antropopresja

\footnotetext{
Zachodniopomorski Uniwersytet Technologiczny w Szczecinie

Słowackiego 17, 71-434 Szczecin

${ }^{1}$ Katedra Fizjologii Roślin i Biochemii

${ }^{2}$ Katedra Ekologii, Ochrony i Kształtowania Środowiska

*corresponding author: entomology@zut.edu.pl
} 


\section{Wstęp / Introduction}

Zieleń miejska poddana jest szczególnie silnej antropopresji wynikającej m.in. z zanieczyszczeń powietrza spalinami, nadmiernego zasolenia gleby związanego z odśnieżaniem ulic, czy niedoborów wody i suszy fizjologicznej. Niewątpliwie najbardziej zagrożone są drzewa usytuowane w bezpośrednim sąsiedztwie ulic i placów. Poszczególne gatunki drzew wykazują różną tolerancję w stosunku do niekorzystnych warunków siedliskowych, która objawia się m.in. spadkiem odporności na patogeny i szkodniki. Są to różnice wynikające także $\mathrm{z}$ cech osobniczych i wieku drzewa. Wygląd zewnętrzny drzew oraz ich zdrowotność stanowią cenną informację o poziomie zanieczyszczenia środowiska miejskiego. $Z$ jednej strony drzewa pełnią funkcję ekologiczną, rekreacyjną i estetyczną, z drugiej strony mogą stanowić wskaźnik degradacji środowiska i stanowić naturalną barierę chroniącą przed zanieczyszczeniami miejskimi. Ochronne pasy zieleni tworzone są przede wszystkim $\mathrm{z}$ drzew liściastych, które ze względu na zrzucanie liści zimą są mniej narażone na wysokie stężenie toksyn (Indeka i Karaczun 1999). Jednym z czynników negatywnie oddziałujących na zieleń $\mathrm{w}$ miastach jest zasolenie, które przyczynia się do spadku odporności drzew, zwiększonej podatności na choroby i żerowanie szkodników oraz częstych deformacji widocznych na liściach i pędach podczas ich rozwoju (Chmielewski 1994).

Celem pracy była ocena i porównanie zdrowotności różnych gatunków drzew nasadzanych wzdłuż ciągów komunikacji miejskiej o zróżnicowanym stopniu zanieczyszczeń spalinami, pod względem występowania patogenów i szkodników.

\section{Materiały i metody / Materials and methods}

Badania terenowe prowadzono w latach 2014-2015, w okresie od maja do października, w nasadzeniach: klonu zwyczajnego Acer platanoides L., klonu jawora Acer pseudoplatanus L. i lipy szerokolistnej Tilia platyphyllos Mill., zlokalizowanych wzdłuż ciągów komunikacyjnych o zróżnicowanym natężeniu ruchu, w różnych częściach aglomeracji szczecińskiej. Szczegółową charakterystykę stanowisk przedstawiono $\mathrm{w}$ tabeli 1 . Obserwacjami objęto 30 drzew na każdym stanowisku o zbliżonej strukturze wiekowej (około 30 lat), po $10 \mathrm{z}$ badanego gatunku. Co 14 dni przeprowadzano kontrolę drzew na obecność grzybów i szkodników. Podczas każdej kontroli zbierano losowo po 10 liści z dolnej partii korony badanego drzewa i poddawano najpierw analizie entomologicznej, potem mikologicznej.

Szkodniki identyfikowano do gatunku w oparciu o cechy morfologiczne i morfometryczne, a także na podstawie objawów ich żerowania (Łabanowski 1996; Łabanowski i Soika 2003). Uszkodzenia drzew przez foliofagi z aparatem gryzącym ustalano metodą szacunkową $\mathrm{w}$ oparciu o stopień uszkodzenia liści, a dla szpecieli w oparciu o obecność wyrośli/deformacji na liściach, traktując je jako rodzaj uszkodzeń. Dla obu grup taksonów przyjęto skalę za
Baranowskim i wsp. (2002): 0 - liście bez uszkodzeń, 1 - słabe porażenie tj. do $10 \%$ uszkodzonej powierzchni liścia, 2 - średnie porażenie tj. od 10 do $25 \%$ uszkodzonej powierzchni liścia, 3 - silne porażenie tj. od 25 do $70 \%$ uszkodzonej powierzchni liścia oraz 4 - bardzo silne porażenie tj. powyżej 70\% uszkodzonej powierzchni liścia. W przypadku stwierdzenia obecności mszyc na liściach określano procent zasiedlonych liści przez te szkodniki przyjmując umownie następującą skalę: 0 - liście bez mszyc; 1 - do $10 \%$ liści z mszycami; 2 - od 10 do $25 \%$ liści z mszycami; 3 - od 25 do $70 \%$ liści z mszycami; 4 - powyżej $70 \%$ liści z mszycami.

Identyfikację grzybów przeprowadzono na podstawie ich cech morfologicznych i morfometrycznych, przy użyciu dostępnych kluczy i przewodników do określania Micromycetes (Sutton 1980; Brandenburger 1985; Braun 1987; Ellis i Ellis 1987). Nasilenie objawów chorobowych powodowanych przez poszczególne patogeny określano na podstawie szacunkowej skali własnej opartej na procentowym udziale liści porażonych przez patogeny, w stosunku do ogólnej liczby przebadanych liści. Dla grzybów z rzędu Erysiphales analizowaną cechą była obecność na liściach nalotu grzybni, zarodników mitomorficznych i owocników mejomorficznych, a w przypadku taksonów powodujących plamistości liści - obecność charakterystycznych dla nich zmian chorobowych oraz struktur grzybów. Podczas szacowania nasilenia objawów powodowanych przez patogeny przyjęto następujące klasy wielkości: 0 - brak liści z objawami chorobowymi i strukturami grzybów; 1 - do $10 \%$ liści $\mathrm{z}$ objawami chorobowymi i strukturami grzybów; 2 - 11-20\% liści z objawami chorobowymi i strukturami grzybów; $3-21-35 \%$ liści z objawami chorobowymi i strukturami grzybów; 4 36-50\% liści z objawami chorobowymi i strukturami grzybów; 5 - powyżej $50 \%$ liści z objawami chorobowymi i strukturami grzybów. Liście z objawami chorobowymi, bezpośrednio po przewiezieniu $\mathrm{z}$ terenu do laboratorium, poddawano szczegółowej analizie; ze zmienionych chorobowo fragmentów wykonano preparaty cięte i analizowano je pod mikroskopem. W przypadku braku dojrzałych struktur grzybów umożliwiających identyfikację patogenów fragmenty roślin inkubowano $\mathrm{w}$ wilgotnych komorach przez 24-48 godzin, a następnie ponownie analizowano.

Stopnień zanieczyszczenia powietrza na badanych stanowiskach przyjęto za danymi udostępnionymi przez Wojewódzki Inspektorat Ochrony Środowiska w Szczecinie. Podczas badań dodatkowo oszacowano wielkość ruchu samochodowego na obydwu stanowiskach na podstawie liczby samochodów poruszających się o wyznaczonej porze $\mathrm{i}$ w określonym odcinku czasu równocześnie w dwóch miejscach badawczych (pojazdy poruszające się w obydwu kierunkach).

W latach 2014-2015 średnia temperatura wiosną oscylowała między $13-19^{\circ} \mathrm{C}$ (rys. 1). Miesiącami najcieplejszymi były: lipiec 2014 roku i sierpień 2015 roku, kiedy średnia temperatura powietrza przekroczyła $20^{\circ} \mathrm{C}$. W tym okresie zaobserwowano wyraźny spadek turgoru tkanek roślinnych (zwiędnięte liście drzew). W 2014 roku zanotowano niższą wilgotność powietrza i mniej opadów w porównaniu z 2015 rokiem. 
Tabela 1. Charakterystyka stanowisk badawczych

Table 1. Description of research sites

\begin{tabular}{|c|c|c|c|}
\hline $\begin{array}{l}\text { Numer stanowiska } \\
\text { Site number }\end{array}$ & $\begin{array}{l}\text { Lokalizacja } \\
\text { stanowiska } \\
\text { Site location }\end{array}$ & $\begin{array}{l}\text { Odległość od ulicy } \\
\text { Distance of a site } \\
\text { from the road } \\
{[\mathrm{m}]}\end{array}$ & $\begin{array}{l}\text { Opis stanowiska } \\
\text { Site description }\end{array}$ \\
\hline I & $\begin{array}{l}\text { ul. Miodowa } \\
\text { Miodowa street }\end{array}$ & $0,5-1$ & $\begin{array}{l}\text { małe natężenie ruchu ulicznego ( } 14 \text { pojazdów samochodowych na } \\
\text { jednostkę pomiaru), zlokalizowany w odległości } 1 \mathrm{~km} \text { od zwartego } \\
\text { kompleksu leśnego „Puszcza Wkrzańska”; po obu stronach drogi } \\
\text { zabudowa mieszkalna } \\
\text { small intensity traffic ( } 14 \text { vehicles per unit of measurement), located at } \\
\text { a distance of } 1 \mathrm{~km} \text { from forest complex "Puszcza Wkrzańska”; resi- } \\
\text { dential buildings on either side of the road }\end{array}$ \\
\hline II & $\begin{array}{c}\text { al. Wojska Polskiego } \\
\text { Wojska Polskiego } \\
\text { street }\end{array}$ & $1,5-3$ & $\begin{array}{l}\text { ciąg komunikacyjny o dużym natężeniu ruchu ( } 69 \text { pojazdów samocho- } \\
\text { dowych na jednostkę pomiaru), z dwupasmowym odcinkiem drogi } \\
\text { oddzielonym torowiskiem tramwajowym; ciąg zadrzewien pomiędzy } \\
\text { drogą a torami oraz na poboczu drogi, w bezpośrednim sąsiedztwie } \\
\text { zwartego kompleksu leśnego „Puszcza Wkrzańska"; brak zabudowy } \\
\text { mieszkalnej } \\
\text { heavy traffic ( } 69 \text { vehicles per unit of measurement); with a dual- } \\
\text { stretch of road separated tram track; the trees between the road and the } \\
\text { tracks and on the side of the road, in the immediate vicinity of the } \\
\text { dense forest complex "Puszcza Wkrzańska"; lack of residential } \\
\text { buildings }\end{array}$ \\
\hline
\end{tabular}
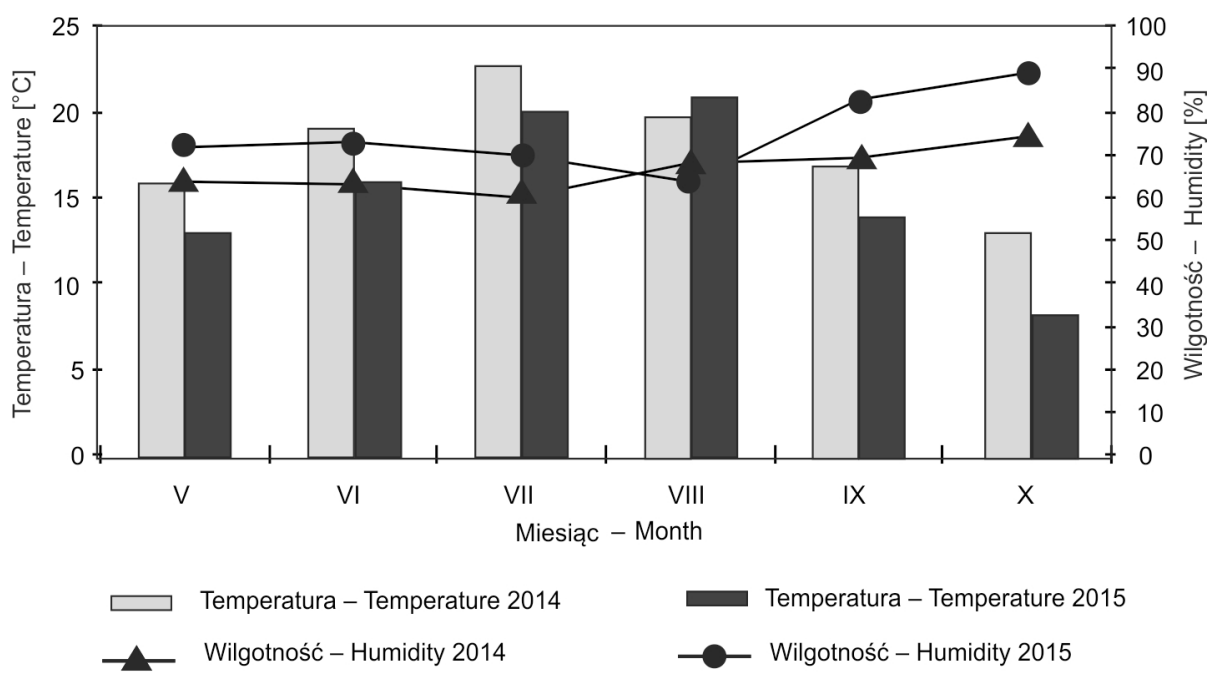

Rys. 1. Średnia miesięczna temperatura powietrza i średnia miesięczna wilgotność powietrza w Szczecinie, w okresie badań (2014-2015)

Fig. 1. Average monthly air temperature and average monthly humidity in Szczecin during the study period (2014-2015)

\section{Wyniki i dyskusja / Results and discussion}

$\mathrm{Na}$ terenie aglomeracji szczecińskiej $\mathrm{w}$ badanym drzewostanie, zlokalizowanym wzdłuż ciągów komunikacji miejskiej o różnym stopniu natężenia ruchu ulicznego, stwierdzono występowanie 11 taksonów Micromycetes i 11 gatunków fitofagów (tab. 2, 3). Wśród roślinożerców dominowały gatunki $\mathrm{z}$ aparatem kłującossącym (63\% taksonów), głównie mszyce (Insecta: Hemiptera, Aphididae) i szpeciele (Acari: Trombidiformes, Eriophyoidea) (tab. 3). Polifagi $\mathrm{z}$ aparatem gryzącym reprezentowane były przez dwa gatunki: piędzika przedzimka Operophtera brumata (Linneaus, 1758) (Lepidoptera: Geometridae), który wystąpił na wszystkich gatunkach badanych drzew, zawsze liczniej w stanowisku o du- żym natężeniu ruchu oraz naliściaka srebrnika Phyllobius argentatus (Linneaus, 1758) (Coleoptera: Curculionidae) odnotowanego na A. pseudoplatanus i Tilia cordata. Na lipach wystąpiły typowe dla tych drzew szkodniki $\mathrm{z}$ aparatem gryzącym, żerujące na liściach: śluzownica lipowa Caliroa annulipes, liczna na obu stanowiskach oraz pryszczarek naliściak lipowy Didymomyia tiliacea. Naliśsciaki $D$. tiliacea masowo odnotowano na stanowisku II, co może sugerować wskaźnikową rolę tego gatunku dla miejsc o wysokim stopniu zanieczyszczenia powietrza spalinami. Hipotezę tą należałoby jednak potwierdzić w obszerniejszych badaniach (tab. 3).

$\mathrm{Na}$ klonach Acer spp. stwierdzono występowanie 3 gatunków mszyc i jednego gatunku szpeciela, a na lipie drobnolistnej $T$. cordata wystąpił jeden gatunek mszycy 
i 2 gatunki szpecieli (tab. 3). Stopień zasiedlenia drzew przez mszyce był zróżnicowany, a obserwowane kolonie tych owadów były najczęściej małej i średniej wielkości (tj. od pojedynczych mszyc na liściu do 30 osobników w kolonii) (za Borowiak-Sobkowiak i wsp. 2012b). Najwyższy stopień zasiedlenia mszyc odnotowano na klonie jaworze A. pseudoplatanus przez zdobniczkę jaworową Drepanosiphum platanoides (Schrank, 1801) i włochatkę klonową czarną Periphyllus testudinaceus (Fernie, 1852) (tab. 3). Jednak nie zaobserwowano wyraźnej zależności między stopniem zanieczyszczenia powietrza spalinami a występowaniem mszyc na badanych gatunkach drzew. Przykładowo liczniejsze kolonie zdobniczki $D$. platanoides zasiedlały liście drzew $A$. pseudoplatanus zlokalizowane przy ulicy o małym natężeniu ruchu ulicznego (stanowisko I), włochatkę $P$. testudinaceus notowano na obu stanowiskach z porównywalnym nasileniem zanieczyszczeń, a zdobniczka lipowa Eucallipterus tiliae wystąpiła tylko na stanowisku II z dużym natężeniem ruchu ulicznego (tab. 3). Liczne badania dotyczące afidofauny potwierdzają fakt, że w warunkach miejskich wśród fitofagów dominują mszyce, najczęściej występujące na roślinach osłabionych, o obniżonej odporności, często poddanych silnej antropopresji (Cichocka i Goszczyński 1991; Wilkaniec 1994; Cichocka i wsp. 1998; Borowiak-Sobkowiak i wsp. 2012a, b; Barczak i Bennewicz 2014). Z przeprowadzonych obserwacji wynika, że ogólnie zagęszczenie i liczebność owadów ssących jest wysoka wzdłuż ciągów komunikacji miejskiej przy jednocześnie niewielkiej ich różnorodności gatunkowej, co koresponduje też z innymi badaniami (Cichocka i Goszczyński 1991; Lubiarz i wsp. 2011; Barczak i Bennewicz 2014). Znaczący udział fitofagów $z$ aparatem ssącym często wiąże się $\mathrm{z}$ niewielkim naturalnym oporem środowiska, w postaci pożytecznych entomofagów (Cichocka i Goszczyński 1991; Chudzicka i wsp. 1998; Winiarska 2000). W skażonym środowisku miejskim zoocenozy ulegają silnej degradacji i tracą zdolność samoregulacji (Pisarski i wsp. 1984). Szereg czynników wpływa na występowanie i zróżnicowanie grup troficznych stawonogów (Winiarska 2000). Należą do nich m.in. zabiegi pielęgnacyjne, które niszczą kryjówki zimowe pożytecznych owadów i pajęczaków, a także zanieczyszczenia spalinami i zasolenie oddziałujące zarówno na faunę, jak i na same rośliny (Pisarski i wsp. 1984). Dane literaturowe wskazują, że zanieczyszczenia które gromadzą się na powierzchni liści i kumulują w tkankach roślinnych mogą zmniejszać atrakcyjność roślin żywicielskich dla roztoczy (Hughes 1988). W przeprowadzonych badaniach zidentyfikowano 3 gatunki roztoczy należące do nadrodziny szpecieli Eriophyoidea, w tym: 2 gatunki na lipie T. cordata i jeden gatunek na jaworze $A$. pseudoplatanus (tab. 3). Roztocze wykazywały zróżnicowaną wrażliwość na zanieczyszczenia spalinami. Najbardziej wrażliwy na skażenia miejskie okazał się pilśniowiec lipowy Eriophyes leiosoma (Nalepa 1892), typowy szkodnik T. cordata (Soika 2007), który na stanowisku o zwiększonym natężeniu ruchu ulicznego występował rzadziej w porównaniu ze stanowiskiem oddalonym od wzmożonego ruchu samochodowego (tab. 3). Natomiast rożkowiec jaworowy Aceria macrorhyncha (Nalepa 1889) i rożkowiec lipowy Erio- phyes tiliae (Pagenstecher, 1857) wystąiły w jednakowym nasileniu na obu stanowiskach. Stwierdzone w badaniach owady i roztocze roślinożerne $\mathrm{w}$ większości stanowią ważne i groźne szkodniki klonów i lipy, które często zasiedlają drzewa o obniżonej odporności na skutek silnej antropopresji (Śliwa 2006; Soika 2007).

Wszystkie rozpoznane Micromycetes były stadiami anamorficznymi workowców. Część (72,7\% zidentyfikowanych grzybów) wywołuje choroby roślin, a pozostałe zasiedlają liście starzejące się lub już objęte zmianami chorobowymi. Największą liczbę gatunków grzybów stwierdzono na liściach $A$. platanoides (6 taksonów). Obecność ponad $83 \%$ taksonów zasiedlających A. platanoides stwierdzono także na $A$. pseudoplatanus. Organizmem, którego nie znaleziono na $A$. pseudoplatanus był Oidium spp., sprawca mączniaka prawdziwego, obydwa te gatunki żywicieli zasiedlał natomiast grzyb Melasmia acerina (Leveille, 1846) powodujący czarną plamistość liści. Na liściach $T$. cordata występowały grzyby z 7 taksonów, z których dwa - Alternaria alternata [(Fries) Keissler, 1912] i Cladosporium spp. znaleziono także na roślinach z rodzaju Acer. Ich obecność w Polsce stwierdzono na wielu gatunkach roślin (Mułenko i wsp. 2008), a ze względu na ich polifagiczność rozpowszechnienie tych organizmów objęło całą kulę ziemską (Marcinkowska 2003). Liście $T$. cordata ze stanowiska o dużym natężeniu ruchu zasiedlone zostały przez częste dla Polski grzyby: Discula umbrinella [(Berkeley i Broome) Morelet, 1973], Passalora microsora [(Saccardo) U. Braun, 1995] i Phyllosticta tiliae (Saccardo i Spegazzini, 1878) (Mułenko i wsp. 2008). Interesująca jest różnica $\mathrm{w}$ stopniu porażenia roślin na badanych stanowiskach przez $D$. umbrinella; takson ten powodował silniejsze zmiany chorobowe u roślin na stanowisku o wysokim natężeniu ruchu $\mathrm{w}$ porównaniu z roślinami ze stanowiska mniej zanieczyszczonego.

Liczba gatunków Micromycetes zasiedlających poszczególne badane gatunki roślin była większa na stanowiskach o większym natężeniu ruchu niż na stanowiskach o natężeniu mniejszym, jednak różnice te nie były znaczne. Grzyby te powodowały większe uszkodzenia roślin na stanowiskach o większym natężeniu ruchu samochodowego w porównaniu z roślinami stanowisk charakteryzujących się mniejszym ruchem (tab. 2). Ponadto stwierdzono, że liście dwóch badanych gatunków roślin (A. pseudoplatanus i $T$. cordata) rosnących na stanowisku o niskim poziomie zanieczyszczeń samochodowych zasiedliło więcej gatunków szkodników niż grzybów, natomiast na stanowisku o dużym natężeniu ruchu liczby taksonów należących do obydwu tych grup (grzybów i szkodników) były porównywalne. W przypadku $A$. platanoides zależności takiej nie zaobserwowano: na obydwu stanowiskach liście rośliny zasiedlało więcej gatunków grzybów niż szkodników.

W badaniach stwierdzono większą liczbę taksonów grzybów na liściach roślin stanowisk o dużym natężeniu ruchu $\mathrm{w}$ porównaniu $\mathrm{z}$ roślinami stanowisk mniej narażonych na zanieczyszczenia komunikacyjne. Podobne spostrzeżenia poczynili Wilkaniec i wsp. (2012) podczas badań prowadzonych w Poznaniu. Wyniki te wiążą się $\mathrm{z}$ negatywnym wpływem zanieczyszczeń powietrza na rośliny. Zanieczyszczenia komunikacyjne są źródłem związków azotu, fosforu, tlenków węgla i wielu metali 
ciężkich (Curzydło 1989 za Grzesiuk i wsp. 1999; Pawluk i wsp. 2011), które oddziałują na liście roślin bezpośrednio, w postaci gazu i pyłu oraz pośrednio, jako substancje zanieczyszczające glebę i pobierane przez system korzeniowy. Pyły osiadające na powierzchni liści zaburzają proces fotosyntezy oraz prowadzą do przegrzewania się tych organów i nadmiernej utraty wody, jednak większe szkody wywołują u roślin zanieczyszczenia w formie gazowej, które wpływają na cały szereg procesów metabolicznych roślin (Grzesiuk i wsp. 1999). Równie toksycznie oddziałują metale ciężkie pobierane wraz z wodą (Gruca-Królikowska i Wacławek 2006). Czynniki te mogą wpływać na podatność roślin na infekcje powodowane przez grzyby, stąd w miejscach o natężonym ruchu komunikacyjnym choroby wywoływane przez Micromycetes rozwijają się silniej (Wilkaniec i wsp. 2012). Stwierdzono, że występowanie chorób roślin w większym nasileniu jest jednym $\mathrm{z}$ objawów zachwiania równowagi biologicznej stanowiska (Mułenko 1998). Z drugiej strony związki zanieczyszczające powietrze oddziałują także na organizmy grzybów, często wpływając na skład gatunkowy tych organizmów. Wśród Micromycetes znane są taksony uznane za wskaźniki jakości środowiska, np. Melasmia acerina (Leith i Fowler 1987; Downing i Richardson 1990; Łuszczyński 2002; Kosiba 2007).

Tabela 2. Występowanie grzybów wzdłuż ciągów komunikacyjnych o różnym stopniu natężenia ruchu ulicznego w sezonie 2014-2015 (najwyższe wartości stwierdzeń w sezonie)

Table 2. The occurrence of fungi in varying degrees of air pollution of urban traffic routes in the season 2014-2015 (the highest values in the season)

\begin{tabular}{|c|c|c|c|c|}
\hline \multirow[t]{2}{*}{$\begin{array}{l}\text { Gatunek } \\
\text { Species }\end{array}$} & \multicolumn{2}{|c|}{$\begin{array}{l}\text { Stanowisko I } \\
\text { Site I } \\
\text { małe natężenie ruchu } \\
\text { low traffic }\end{array}$} & \multicolumn{2}{|c|}{$\begin{array}{l}\text { Stanowisko II } \\
\text { Site II } \\
\text { duże natężenie ruchu } \\
\text { heavy traffic }\end{array}$} \\
\hline & 2014 & 2015 & 2014 & 2015 \\
\hline \multicolumn{5}{|c|}{ Acer platanoides L. } \\
\hline Alternaria alternata (Fries) Keissler & 2 & 3 & 3 & 3 \\
\hline Cladosporium spp. & 1 & 2 & 2 & 3 \\
\hline Discula campestris (Passerini) Arx & 0 & 0 & 3 & 4 \\
\hline $\begin{array}{l}\text { Melasmia acerina Leveille [st. mejomorficzne - st. } \\
\text { mejomorphous Rhytisma acerinum (Persoon) Fries] }\end{array}$ & 1 & 2 & 5 & 5 \\
\hline $\begin{array}{l}\text { Melasmia punctata Saccardo \& Roumeguere [st. } \\
\text { mejomorficzne - st. mejomorphous Rhytisma punctatum } \\
\text { (Persoon) Fries] }\end{array}$ & 0 & 0 & 2 & 1 \\
\hline $\begin{array}{l}\text { Oidium sp. (st. mejomorficzne - st. mejomorphous Uncinula } \\
\text { tulasnei Fuckel) }\end{array}$ & 0 & 0 & 1 & 1 \\
\hline
\end{tabular}
tulasnei Fuckel)

\begin{tabular}{|c|c|c|c|c|}
\hline Alternaria alternata (Fries) Keissler & 2 & 3 & 4 & 2 \\
\hline Cladosporium spp. & 3 & 3 & 3 & 4 \\
\hline Discula campestris (Passerini) Arx & 0 & 0 & 2 & 3 \\
\hline $\begin{array}{l}\text { Melasmia acerina Leveille [st. mejomorficzne - st. } \\
\text { mejomorphous Rhytisma acerinum (Persoon) Fries] }\end{array}$ & 1 & 1 & 3 & 3 \\
\hline $\begin{array}{l}\text { Melasmia punctata Saccardo \& Roumeguere [st. } \\
\text { mejomorficzne - st. mejomorficzne Rhytisma punctatum } \\
\text { (Persoon) Fries] }\end{array}$ & 0 & 0 & 1 & 0 \\
\hline
\end{tabular}
mejomorficzne -
(Persoon) Fries]

Tilia cordata Mill

Alternaria alternata (Fries) Keissler

Asteromella tiliicola (Oudemans.) Arx

Cladosporium spp.

Discula umbrinella (Berkeley \& Broome) Morelet

Passalora microsora (Saccardo) U. Braun

Phyllosticta tiliae Saccardo \& Spegazzini

Stemphylium botryosum Wallroth

\begin{tabular}{|l|l|l|l}
1 & 1 & 3 & 4 \\
2 & 2 & 0 & 0 \\
1 & 1 & 4 & 4 \\
1 & 2 & 4 & 5 \\
0 & 0 & 2 & 3 \\
0 & 0 & 1 & 2 \\
0 & 0 & 2 & 2 \\
\hline
\end{tabular}

Nasilenie objawów chorobowych: 0 - liście bez objawów chorobowych i struktur grzybów; 1 - do $10 \%$ liści z objawami chorobowymi i strukturami grzybów; $2-11-20 \%$ liści z objawami chorobowymi i strukturami grzybów; $3-21-35 \%$ liści z objawami chorobowymi i strukturami grzybów; $4-36-50 \%$ liści z objawami chorobowymi i strukturami grzybów; 5 - powyżej $50 \%$ liści z objawami chorobowymi i strukturami grzybów - Severity of symptoms: 0 - no symptoms and structures of fungi; 1 - up to $10 \%$ leaves with symptoms and structures of fungi; 2 - $11-20 \%$ leaves with symptoms and structures of fungi; $3-21-35 \%$ leaves with symptoms and structures of fungi; $4-36-50 \%$ leaves with symptoms and structures of fungi; 5 - more than $50 \%$ leaves with symptoms and structures of fungi 
Tabela 3. Występowanie szkodników wzdłuż ciągów komunikacyjnych o różnym stopniu natężenia ruchu ulicznego w sezonie 2014-2015 (najwyższe wartości stwierdzeń w sezonie)

Table 3. The occurrence of pests in varying degrees of air pollution of urban traffic routes in the season 2014-2015 (the highest values in the season)

\begin{tabular}{|c|c|c|c|c|}
\hline \multirow[t]{2}{*}{$\begin{array}{l}\text { Gatunek } \\
\text { Species }\end{array}$} & \multicolumn{2}{|c|}{$\begin{array}{c}\text { Stanowisko I } \\
\text { Site I } \\
\text { małe natężenie ruchu } \\
\text { low traffic }\end{array}$} & \multicolumn{2}{|c|}{$\begin{array}{c}\text { Stanowisko II } \\
\text { Site II } \\
\text { duże natężenie ruchu } \\
\text { heavy traffic }\end{array}$} \\
\hline & 2014 & 2015 & 2014 & 2015 \\
\hline \multicolumn{5}{|c|}{ Acer platanoides L. } \\
\hline Operophtera brumata L.* & 1 & 1 & 2 & 1 \\
\hline Periphyllus testudinaceus Fernie** & 1 & 1 & 1 & 1 \\
\hline Periphyllus aceris L.** & 0 & 0 & 1 & 2 \\
\hline \multicolumn{5}{|c|}{ Acer pseudoplatanus L. } \\
\hline Operophtera brumata L.* & 1 & 1 & 1 & 2 \\
\hline Phyllobius argentatus L.* & 0 & 0 & 0 & 1 \\
\hline Drepanosiphum platanoides Schrk.** & 3 & 2 & 1 & 2 \\
\hline Periphyllus testudinaceus Fernie** & 1 & 2 & 2 & 2 \\
\hline Aceria macrorhyncha Nalepa* & 1 & 1 & 1 & 1 \\
\hline \multicolumn{5}{|c|}{ Tilia cordata Mill. } \\
\hline Operophtera brumata L.* & 1 & 1 & 2 & 1 \\
\hline Phyllobius argentatus L.* & 0 & 1 & 0 & 0 \\
\hline Didymomyia tiliacea Bremi* & 0 & 0 & 2 & 3 \\
\hline Caliroa annulipes Klug* & 2 & 3 & 2 & 3 \\
\hline Eucallipterus tiliae L.** & 0 & 0 & 1 & 1 \\
\hline Eriophyes tiliae Pgst.* & 3 & 3 & 2 & 3 \\
\hline Eriophyes leiosoma Nalepa* & 3 & 2 & 0 & 1 \\
\hline
\end{tabular}

*Procent uszkodzeń liści: 0 - liście bez uszkodzeń, 1 - do $10 \%$ uszkodzonej powierzchni liścia przez szkodniki, 2 - od 10 do $25 \%$ uszkodzonej powierzchni liścia przez szkodniki, 3 - od 25 do $70 \%$ uszkodzonej powierzchni liścia przez szkodniki oraz 4 - powyżej $70 \%$ uszkodzonej powierzchni liścia przez szkodniki

*The percentage damage of the leaves: 0 - no visible damage of the leaves; 1 - up to $10 \%$ surface of the leaves damaged by pests; 2 - from $10 \%$ to $25 \%$ surface of the leaves damaged by pests; 3 - from $25 \%$ to $70 \%$ surface of the leaves damaged by pests; more than $70 \%$ surface of the leaves damaged by pests

**Procent zasiedlonych liści przez mszyce: 0 - liście bez mszyc; 1 - do $10 \%$ liści z mszycami; 2 - od 10 do 25\% liści z mszycami; 3 - od 25 do $70 \%$ liści z mszycami; 4 - powyżej $70 \%$ liści z mszycami

**The percentage of infested leaves by aphids: 0 - the leaves without aphids; 1 - up to $10 \%$ of the leaves with aphids; 2 - from $10 \%$ to $25 \%$ of the leaves with aphids; 3 - more than $70 \%$ surface of the leaves with aphids

Ograniczenie występowania wielu gatunków Micromycetes, np. Cronartium flaccidum [(Albertini i Schweinitz) G. Winter, 1880], Lophodermium pinastri [(Schrader) Chevallier, 1826], Melampsora pinitorqua (Rostrupp. 1889) i Microsphaera alphitoides (Griffon i Maublanc, 1912), wiązane jest $\mathrm{z}$ podwyższonym stężeniem $\mathrm{SO}_{2}$ w powietrzu (Grzywacz 1973a, b, c; Grzywacz i Ważny 1973 za Sucharzewska 2013), natomiast inne reagują zmianami rozwojowymi na podniesiony poziom związków azotu lub inne zanieczyszczenia komunikacyjne (Sucharzewska 2007 za Sucharzewska 2013). W trakcie obecnych badań znaleziono dwa gatunki szczególnie wrażliwe na poziom zanieczyszczeń powietrza - M. acerina i $M$. punctata (Saccardo i Roumeguere, 1882). Interesujące są różnice w stopniu zasiedlenia przez nie roślin na badanych stanowiskach. Grzyb M. acerina spowodował większe uszkodzenia roślin na stanowisku o większym natężeniu ruchu $\mathrm{w}$ porównaniu ze stanowiskiem słabiej zanieczyszczonym, a $M$. punctata znaleziono jedynie na stanowisku o dużym natężeniu ruchu. Wprawdzie dane literaturowe jednoznacznie wskazują, że czynnikiem ograniczającym występowanie $M$. acerina są między innymi związki siarki i azotu oraz szereg metali ciężkich (Downing i Richardson 1990; Kosiba 2007), jednak w badaniach Wilkaniec i wsp. (2012) grzyb ten spowodował większe nasilenie zmian chorobowych na roślinach rosnących w warunkach silniejszego stresu komunikacyjnego. W przypadku badań własnych występowanie i wysoki stopień uszkodzenia roślin występujących przy często uczęszczanym szlaku komunikacyjnym może tłumaczyć lokalizacja drogi. Prawdopodobnie bliskie sąsiedztwo dużej ilości drzew liściastych i iglastych przyczyniło się do pochłonięcia zanieczyszczeń powietrza (Dobrzańska 2012), co tym samym stworzyło lepsze warunki dla rozwoju grzybów $\mathrm{z}$ rodzaju Melasmia.

W odpowiedzi na silną antropopresję drzewa wykształciły szereg mechanizmów obronnych. Wiele gatunków posiada zdolność gromadzenia metali ciężkich w wysokich stężeniach w tkankach, w sposób dla nich jak najmniej toksyczny, prowadząc nawet do ich detoksykacji bądź 
wręcz ograniczając wnikanie szkodliwych substancji do komórek (Baranowska-Morek 2003; Ghosh i Singh 2005; Siwek 2008; Ociepa-Kubicka i Ociepa 2012). Odporność drzew na niekorzystne czynniki biotyczne lub abiotyczne może wynikać z ich budowy anatomiczno-morfologicznej. Wielkość i kolor liści, obecność włosków parzących, bruzd czy kolców na liściach, grubość i nasycenie kutikuli woskiem, grubość ścian komórkowych, a także wielkość oraz liczba aparatów szparkowych mogą znacząco ograniczać występowanie patogenów i szkodników na roślinie (Gutowski i wsp. 1992; Leszczyński 2001; Sytykiewicz 2007). Podobnie skład biochemiczny tkanek roślinnych może stanowić barierę obronną przed niekorzystnymi czynnikami biotycznymi. Przykładowo wytwarzanie specyficznych białek obronnych blokuje działanie enzymów trypsyny i chymotrypsyny, rozkładających białko roślinne, co uniemożliwia jego trawienie i przyswajanie przez fitofagi (Harborne 1997). Zmniejszenie zawartości metabolitów np. białek czy wolnych aminokwasów uniemożliwia prawidłowy rozwój i rozmnażanie się owadów. Do tej grupy zaliczamy również allelozwiązki. Większość $\mathrm{z}$ nich jest zlokalizowana w wakuolach i ścianach komórkowych peryferyjnych tkanek roślinnych i może wykazywać właściwości repelentne w stosunku do wielu pospolitych szkodników roślin. Ważnymi czynnikami decydującymi o wartości smakowej danej rośliny są obok cukrów także fosfolipidy, witaminy czy mikroelementy. Reakcja roślin na żerowanie fitofagów objawia się obniżeniem zawartości tych składników w tkankach, co powoduje zaniechanie żerowania i zmianę żywiciela przez roślinożercę (Leszczyński 2001; Syty- kiewicz 2007). Reasumując przy nasadzeniach miejskich powinny być uwzględniane gatunki drzew nie tylko odporne na zanieczyszczenia, ale również wyróżniające się niewielkim stopniem zasiedlenia przez szkodliwe fitofagi (Łabanowski i Soika 2008) i patogeny.

\section{Wnioski / Conclusions}

1. Drzewa o obniżonej odporności na skutek silnej antropopresji, rosnące $\mathrm{w}$ bezpośrednim sąsiedztwie ulicy o wzmożonym ruchu samochodowym, są na ogół liczniej zasiedlane przez patogeny i szkodniki. Na stanowisku o mniejszym natężeniu ruchu ulicznego odnotowano mniej taksonów szkodliwych, chociaż różnice te były niewielkie. Czynnikami sprzyjającymi występowaniu szkodników i patogenów były: wysoka temperatura i wilgotność względna powietrza.

2. Lipa drobnolistna $T$. cordata należy do drzew szczególnie wrażliwych na patogeny i szkodniki. Łącznie odnotowano na niej 7 taksonów fitofagów i 7 taksonów grzybów. Stopień porażenia lip przez grzyby i szkodniki był wyraźnie wyższy na stanowisku o wzmożonym natężeniu ruchu komunikacyjnego.

3. Nie potwierdzono zależności między występowaniem gatunku wskaźnikowego $M$. acerina a poziomem zanieczyszczenia powietrza. Grzyb ten pojawił się na obydwu badanych stanowiskach, jednak w stopniu silniejszym w miejscu o większym natężeniu ruchu, co przeczy wcześniejszym doniesieniom o jego wysokiej wrażliwości na skażenia powietrza spalinami.

\section{Literatura / References}

Baranowska-Morek A. 2003. Roślinne mechanizmy tolerancji na toksyczne działanie metali ciężkich. Kosmos 52 (2-3): 283-295.

Baranowski T., Parus A., Fajfer B. 2002. Występowanie szrotówka kasztanowcowiaczka [Cameraria ohridella (Deschka \& Dimić)] na kasztanowcach w Poznaniu w latach 2000-2001. [The occurrence of Cameraria ohridella (Deschka \& Dimić) on Aesculus hippocastanum in Poznań in 2000-2001]. Progress in Plant Protection/Postępy w Ochronie Roślin 42 (2): 654-657.

Barczak T., Bennewicz J. 2014. Mszyce środowisk zurbanizowanych. s. 65-75. W: "Urban Fauna. Animal, Man, and the City Interactions and Relationships" (P. Indykiewicz, J. Böhner, eds.). ArtStudio, Bydgoszcz, 397 pp.

Borowiak-Sobkowiak B., Wilkaniec B., Durak R. 2012a. Afidofauna (Hemiptera: Aphidoidea) drzew i krzewów zieleni miejskiej Poznania. Część 2: Ogród Zoologiczny. Nowe Zoo. Wiadomości Entomologiczne 31 (4): 221-229.

Borowiak-Sobkowiak B., Wilkaniec B., Durak R. 2012b. Afidofauna drzew i krzewów zieleni miejskiej Poznania. Część 1: Ogród Zoologiczny. Stare Zoo. Wiadomości Entomologiczne 31 (3): 141-152.

Brandenburger W. 1985. Parasitische Pilze an Gefäßpflanzen in Europa. Fischer, Stuttgart, 1248 pp.

Braun U. 1987. A Monograph of the Erysiphales (Powdery Mildews). Nova Hedwigia, Berlin, 700 pp.

Chmielewski W. 1994. Wieloletnie obserwacje fenologiczne drzew i skład chemiczny liści w ocenie stopnia zanieczyszczenia środowiska miejskiego. s. 211-218. W: „Reakcje biologiczne drzew na zanieczyszczenia przemysłowe” (R. Siwicki, red.). III Krajowe Sympozjum. Kórnik, 21-26 maja 1994. Wyd. Sorus, 631 ss.

Chudzicka E., Skibińska E., Winiarska G. 1998. Zasiedlanie środowiska miejskiego przez owady na przykładzie Warszawy. s. 47-56. W: „Fauna miast” (T. Barczak, P. Indykiewicz, red.). Wyd. ATR, Bydgoszcz, 263 ss.

Cichocka E., Goszczyński W. 1991. Mszyce zasiedlające drzewa uliczne w Warszawie. s. 9-18. W: „Mszyce i ich bionomia, szkodliwość i wrogowie naturalni” (E. Cichocka, red.). PAN, Warszawa, 119 ss.

Cichocka E., Goszczyński W., Szybczyski K. 1998. Mszyce i ich naturalni wrogowie na klonach w Warszawie. s. 83-88. W: „Fauna miast" (T. Barczak, P. Indykiewicz, red.). Wyd. ATR, Bydgoszcz, 263 pp.

Curzydło J. 1989. Ołów i cynk w roślinach i glebach w sąsiedztwie drogowych szlaków komunikacyjnych. Zeszyty Naukowe Akademii Rolniczej w Krakowie 127, 70 ss.

Dobrzańska B.M. 2012. Zagrożenie lasów. W: „Ochrona środowiska przyrodniczego” (B. Dobrzańska, G. Dobrzański, D. Kiełczewski, red.). PWN, Warszawa, 459 ss.

Downing P., Richardson D.H.S. 1990. Leafyeasts as indicators of air quality in Europe. Environmental Pollution 66 (3): $223-235$.

Ellis M.B., Ellis J.P. 1987. Microfungi of Land Plants. An Identification Handbook. Croom Helm, London, 818 pp.

Ghosh M., Singh S.P. 2005. A review of phytoremediation of heavy metals and utilization of its byproducts. Applied Ecology and Environmental Research 3 (1): 1-18. 
Gruca-Królikowska S., Wacławek W. 2006. Metale w środowisku. Cz. II. Wpływ metali ciężkich na rośliny. Chemia Dydaktyka Ekologia Meteorologia 11 (1-2): 41-56.

Grzesiuk S., Koczowska I., Górecki R. 1999. Fizjologiczne podstawy odporności roślin na choroby. Wyd. ATR, Olsztyn, 284 ss.

Grzywacz A. 1973a. Sensitivity of Fomes annosus Fr. Cooke and Schizophyllum commune Fr. to air pollution with sulphur dioxide. Acta Societatis Botanicorum Poloniae 42 (3): 347-360.

Grzywacz A. 1973b. Występowanie grzybów chorobotwórczych w nadleśnictwie Panewnik objętym wpływem przemysłowych zanieczyszczeń powietrza. Zeszyty Naukowe Akademii Rolniczej we Wrocławiu, Leśnictwo 19: 91-99.

Grzywacz A. 1973c. Występowanie niektórych grzybów chorobotwórczych w lasach okręgów przemysłowych. Sylwan 9: $29-37$.

Grzywacz A., Ważny J. 1973. The impact of industrial air pollutants on the occurrence of several important pathogenic fungi of forest trees in Poland. European Journal of Forest Pathology 3: 129-141.

Gutowski J., Królik R., Partyka M. 1992. Studia nad biologią, występowaniem i znaczeniem gospodarczym w Polsce bogatków z rodzaju Paenops Dejan (Coleoptera: Buprestidae). Prace Instytutu Badawczego Leśnictwa 736: 77-192.

Harborne J.B. 1997. Ekologia biochemiczna. PWN, Warszawa, 351 ss.

Hughes P.R. 1988. Insect populations on host plants subjected to air pollution. In: "Plant Stress - Insect Interactions" (E.A. Heinrichs, ed.). John Wiley and Sons, Inc, New York 8: 249-319.

Indeka L., Karaczun Z. 1999. Akumulacja wybranych metali ciężkich w glebach przy ruchliwych trasach komunikacyjnych. Ekologia i Technika VII, 6 (99): 174-180.

Kosiba P. 2007. Impact of air pollution on the occurrence of Rhytisma acerinum "tar-spot" on maple leaves. Acta Societatis Botanicorum Poloniae 76 (4): 333-343.

Leith I.D., Fowler D. 1987. Urban distribution of Rhytisma acerinum (Pers.) Fries (tar spot) on sycamore. New Phytologist 108 (2): $175-181$.

Leszczyński B. 2001. Naturalna odporność roślin na szkodniki. s. 87-108. W: „Biochemiczne oddziaływania środowiskowe” (W. Oleszek, K. Głowniak, B. Leszczyński, red.). Akademia Medyczna, Lublin, 314 ss.

Lubiarz M., Cichocka E., Goszczyński W. 2011. Landscape type and species richness and composition of Arthropoda. Part. II. Urban landscape. Aphids and Other Hemipterous Insects 17: 41-53.

Łabanowski G. 1996. Klucz do oznaczania szkodników roślin ozdobnych na podstawie uszkodzeń. s. 232-385. W: „Diagnostyka szkodników roślin i ich wrogów naturalnych. T 2.” (J. Boczek, red.). SGGW Warszawa, 385 ss.

Łabanowski G., Soika G. 2003. Szkodniki ozdobnych drzew liściastych. Plantpress, Kraków, 126 ss.

Łabanowski G., Soika G. 2008. Zasiedlenie drzew i krzewów ozdobnych przez szkodliwe roztocze i owady w środowisku zurbanizowanym. s. 571-576. W: „Fauna miast. Ochronić różnorodność biologiczną w miastach” (P. Indykiewicz, L. Jerzak, T. Barczak, red.). Wyd. Sar „Pomorze”, Bydgoszcz, 634 ss.

Łuszczyński J. 2002. Możliwości i sposoby wykorzystania grzybów w monitoringu środowiska. Regionalny Monitoring Środowiska Przyrodniczego. Kieleckie Towarzystwo Naukowe, Kielce 3: 53-55.

Marcinkowska J. 2003. Oznaczanie rodzajów grzybów ważnych w patologii roślin. Fundacja Rozwój SGGW, Warszawa, 328 ss.

Mułenko W. 1998. Mikroskopowe grzyby fitopatogeniczne w strukturze naturalnych zbiorowisk leśnych. Uniwersytet Marii Curie-Skłodowskiej, Lublin, 188 ss.

Mułenko W., Majewski T., Ruszkiewicz-Michalska M. 2008. A Preliminary Checklist of Micromycetes in Poland. W. Szafer Institute of Botany, Polish Academy of Sciences, Kraków, 752 pp.

Ociepa-Kubicka A., Ociepa E. 2012. Toksyczne oddziaływanie metali ciężkich na rośliny, zwierzęta i ludzi. Inżynieria i Ochrona Srodowiska 15 (2): 169-180.

Pawluk K., Fronczyk J., Garbulewski K. 2011. Przepuszczalne bariery reaktywne w ochronie środowiska wzdłuż tras komunikacyjnych. s. 137-144. W: „Nowoczesne rozwiązania w inżynierii i ochronie środowiska. Tom II” (S. Anisimov, J. Danielewicz, E. Szczechowiak, G. Bartnicki, M. Klimczak, red.). Oficyna Wydawnicza Politechniki Wrocławskiej, Wrocław, 393 ss.

Pisarski B., Chudzicka E., Nowakowski E., Skibińska E., Jędryczkowski W. 1984. Rola fauny na terenach zielonych miast, na przykładzie Warszawy. s. 203-219. W: „Wpływ zieleni na kształtowanie środowiska miejskiego” (H.B. Szczepanowska, red.). PWN, Warszawa.

Siwek M. 2008. Rośliny w skażonym metalami ciężkimi środowisku poprzemysłowym. Część II. Mechanizmy detoksyfikacji i strategie przystosowania roślin do wysokich stężeń metali ciężkich. Wiadomości Botaniczne 52 (3/4): 7-23.

Soika G. 2007. Szpeciele z rodzaju Eriophyes występujące na lipach w parkach. [Eriophyoid mites from Eriophyes genus occurring on lime trees in parks]. Progress in Plant Protection/Postępy w Ochronie Roślin 47 (1): 374-377.

Sucharzewska E. 2007. Strategie życiowe wybranych gatunków z rzędu Erysiphales w warunkach zróżnicowanej antropopresji. Rozprawa doktorska. Katedra Mykologii. Uniwersytet Warmińsko-Mazurski w Olsztynie.

Sucharzewska E. 2013. Grzyby saprotroficzne i fitopatogeniczne w monitoringu ekosystemów lądowych. s. 100-124. W: „Biologiczne metody oceny stanu środowiska. Tom 1. Ekosystemy lądowe” (M. Dynowska, H. Ciecierska, red.). Uniwersytet WarmińskoMazurski w Olszynie, 268 ss.

Sutton B.C. 1980. The Coelomycetes. CMI, Kew, 696 pp.

Sytykiewicz H. 2007. Biochemiczne i anatomiczne aspekty żerowania mszycy czeremchowo-zbożowej (Rhopalosiphum padi L.) na żywicielu pierwotnym. Rozprawa doktorska. Akademia Podlaska, Siedlce, 165 ss.

Śliwa P. 2006. The main pests of ornamental trees grown in Kraków. Visnyk of Lviv University Biology Series 42: 97-100.

Wilkaniec B. 1994. Aphidofauna of selected tree species in the urban area of Poznań. Aphids and Other Homopterous Insects 4: 71-79.

Wilkaniec B., Breś W., Frużyńska-Jóźwiak D., Borowiak-Sobkowiak B., Wilkaniec A. 2012. The assessment of chemical properties of the soil, the chemical composition of leaves and the occurrence of diseases on Acer platanoides and Tilia cordata in selected sites of urban greenery in Poznań. Phytopathologia 65: 13-22.

Winiarska G. 2000. Owady w mieście - wybrane zagadnienia dotyczące zagrożenia i ochrony entomofauny w ekosystemie miejskim. Wiadomości Entomologiczne 18, Supl. 2: 121-128. 